\title{
THE REFORM OF THE BRAZILIAN ANTI- DUMPING REGIME: A PARTIAL REVIEW OF THE DETERMINANTS AND THE IMPLICATIONS OF DECREE 8,058/2013
}

\author{
Hélio Henkin ${ }^{1}$ \\ Rafael Pentiado Poerschke ${ }^{2}$ \\ Ricardo Dias da Silva ${ }^{3}$
}

\section{Introduction}

The degree of trade integration between countries has gradually advanced since the signing of the General Agreement on Tariffs and Trade (GATT) in 1947. Its successor, the World Trade Organization (WTO), established in 1995, intensified this trend and contributed to the members of the trade system becoming even more interdependent, multilateral and regional. The progress towards free trade has been informed both by the guidelines derived from the International System and by the engagement of countries on different fronts of liberalization at the bilateral and plurilateral levels. This reinforces the need to look at the eminently political component that sets the tone and guides government decisions in their different domains (Lindbolm I98I).

In the history of the capitalist system, due to political hegemony, geographical factors or their own histories, various nations dominated trade. Despite the asymmetries and hierarchies that structure this system, the existence of margins of action - contextual and contingent - is recognized, which allow governments to issue decisions capable of affecting markets beyond their borders and, conversely, making decisions influenced

\footnotetext{
I Professor from the Department of Economics at Universidade Federal do Rio Grande do Sul (UFRGS), Brazil.

$2 \mathrm{PhD}$ in International Strategic Studies from Universidade Federal do Rio Grande do Sul (UFRGS), Brazil. Member of the ABCI Institute - Brazilian International Trade Scholar, Inc. (Washington, DC).

$3 \mathrm{PhD}$ in Social Sciences from Universidade Federal Rural do Rio de Janeiro (UFRRJ), Brazil. Doctoral internship (PDSE/CAPES) at Center de Coopération Internationale en Recherche Agronomique pour le Développement (Cirad, Montpellier).
} 
by external factors. In the drive to stimulate the maximization of domestic economic welfare, these decisions carry a component derived from the pressure of certain stakeholders and class entities. When negatively affected, the latter will seek to mitigate the potentially deleterious effects of trade by way of proposals to (re)formulate trade and industrial policies that are more favorable to their purposes.

Following the prohibition of traditional trade policy instruments during the GATT period, such as voluntary export quotas and restrictions, as well as the limitation on the collection of nominal fees, trade policy measures of a different character started to be implemented. In the meantime, trade defense instruments play a leading role in the trade policy of countries that are part of the multilateral trading system. This data is indicative of the multilevel determinants of the foreign policy, in general, and the foreign trade policy, in particular, as formulated by Putnam (I988) and whose analytical yields are examined in this work.

The current scenario points to an increase in the number of member countries that are frequent users of trade defense instruments, in particular temporary barriers to trade in goods. In the WTO, the number of users of these barriers exceeds that of non-users. Until the I980s, the application of this type of measure was restricted to the United States, Canada, Australia and the European Union. Twenty years later, developing countries have taken a more active position in the group of users of temporary measures.

Trade defense measures are part of a broad set of instruments available to a government to regulate trade in goods. One of them, now regulated by the GATT/WTO Anti-Dumping Agreement (ADA), states that any and all application of anti-dumping duties requires evidence that dumping is the main cause of the damage to the domestic industry. The application of temporary barriers, in turn, does not have a limit, but requires a procedure that must start from the industry or a representative portion of it. The industry that is affected petitions for an investigation into unfair trade practices, and the government is left to investigate the case making use of an investigating authority. If there is satisfactory evidence to justify new barriers, provisional or definitive duties can then be applied. According to the ADA, the application of the duties seeks to neutralize the damage resulting from the practice of dumping, and distances itself from the principle of mere temporary relief for the industry.

Data from the Global Antidumping Database (GAD) regarding the number of requests for further investigations pointed to India as the country where more petitions were received, followed by the United States and Brazil. Bown (2012) showed that in 2012 these numbers were $13 \%$ higher than in 
2009 , and $67 \%$ higher than in 2007 . The author's findings also suggest that most of the new measures targeted imports from China and other developing countries - a phenomenon called "South-South protectionism", according to Feinberg (20I0). The author believes that this process signals the emergence of an "issue" in the trade chain between developing countries.

In 20II, the inauguration of the first Dilma administration preceded a period of more acute changes in trade policy and defense. In this context, in 2012 and again in 2013, it was Brazil's turn to be the most extensive user of anti-dumping measures. In 2013 alone, Brazil notified the WTO of 30 new anti-dumping measures in force, most of them being against Asian countries, especially China. Alone, Brazil accounted for $20 \%$ of the total measures imposed that year.

The leadership in the users ranking concurred with the beginning of a political and economic conjuncture favorable to the political debate on the milestones of trade defense in Brazil. Both the experiences and learnings gained over the course of the previous milestone and the preferences and political goals of stakeholders shaped during this course, contributed to this critical moment (Pierson 2004). Therewith, the first Dilma administration (20II-20I4), representing a labor party, was characterized by a significant number of changes in foreign trade policy, combined with a high demand in the industry for anti-dumping measures.

This study examines the development and reform of the anti-dumping regime in Brazil as an example of the further development of a multilateral trade system proposed by the World Trade Organization. Brazil's long history of leadership in the Rounds, as well as its emergence among users of temporary barriers, illustrate the fact that developing countries successfully participate in vouching for the multilateral system. Using the WTO AntiDumping Agreement as a model for its own regulatory framework, Brazil also shows the importance of participating more actively in thematic tables of the Rounds promoted by the WTO. Firstly, countries can make use of the topics raised in the documents that circulate in order to serve as an aid for the implementation of the domestic anti-dumping policy. Furthermore, this practice can ensure that domestic legislation will have greater compliance with international obligations, ensuring predictability and avoiding constraints via the Dispute Settlement Body.

The anti-dumping legislation, when it comes to government projects, crystallizes a unique opportunity to analyze the details of the process of developing public policies aimed at the international trade. The Fernando Henrique Cardoso administration catalyzed the change in the issue of Brazilian foreign and trade policy, as it was responsible for internalizing 
rules and creating the Brazilian Department of Trade Defense (DECOM). However, the Luiz Inácio Lula da Silva administration created anti-avoidance rules $^{4}$, in addition to having gathered the team in Brasilia, almost Io years after the creation of DECOM (interview with Welber Barral, former Secretary of Foreign Trade of the Foreign Trade Chamber (CAMEX), 2007-20II). As previously considered, during the FHC administration, the scope of DECOM was limited, since its team was divided between Rio de Janeiro and Brasília.

Although trade defense was once the subject of the former president's government plan, mainly as a reflection of the creation of the WTO and Mercosur, this topic would assume a key role in the first Dilma administration. To support and seal a commitment to the industry, reforming anti-dumping legislation became one of the main priorities of the Dilma administration.

Thus, the article's main goal is to understand the policymaking of Decree 8,058 , of 2013 , shedding light on the main determinants of its formulation and some implications of this modernization of the regulation for the application of anti-dumping measures in Brazil. In this sense, this paper is guided by the following specific goals:

a. understand the course of the reform of the Brazilian anti-dumping regime;

b. describe and analyze the fluctuations of Brazil's anti-dumping policy, emphasizing the role of policymakers;

c. present the main elements of the modernization of the regulatory framework that started to regulate AD investigations.

\section{Methodological Procedures and Operationalization of Research}

Through a theoretically oriented process tracking, we refer back to the first wave of strengthening of the Department of Trade Defense in Brazil, dating from the end of the Itamar Franco administration and the first Fernando Henrique Cardoso administration, we analyze the incremental adjustments executed during in the Lula administration and arrive at the first Dilma administration in the middle of the inflection represented by the Greater Brazil Plan (PBM). This is relevant to the extent that the understanding of the determinants that allow adjustments, recalibrations or changes in trade policy requires understanding of the mechanisms that maintained the previous standard.

4 Under Lula administration, a public tender was held that appointed 40 new Foreign Trade Analysts. 
During this journey, PBM was responsible, among other things, for the inclusion of measures to strengthen trade defense as key items of the industrial policy. Given an old industry demand, guidelines specifically for trade policy and defense were included in the Plan, which are synthetically inventoried and analyzed below. For this stage, the research took on a more exploratory tone, since few analyses were developed on the subject, and, therefore, the purpose was to outline an overview of the possible advances and challenges posed by the PBM to trade defense in general.

Therefore, the option was also to add methodological resources capable of providing robust evidence for the study, such as: bibliographic research and review, in-depth interviews and documentary analysis. The main axis of the analysis on the modernization of the normative framework triggered by the PBM was the interlocution of the development and implementation of new Decree 8,058/2013, in which we aimed for open and semi-structured interviews with policymakers and other actors involved in the issue of the Decree. The sample group was heard between June 2015 and July 2020. At first, interviewees were selected from a triangulation with the bibliography and the official documents analyzed. In relation to the latter, the survey sought, at the same time, to recover the contents of the propositions that circulated and to scan the chain of command of roles and positions of power of these policymakers and how these influenced the process.

This documentary survey was carried out through successive incursions into the legal and normative framework (Laws, Decrees, Ordinances, Resolutions, etc.) that are related to the trade defense policy; in addition, it considered the official publications of the class entities (National Confederation of Industry - CNI, and Federation of Industries of the State of São Paulo - FIESP) and the information developed and disclosed by the Department of Trade Defense, the core entity in this process. As you will see throughout the following sections, a close link exists between the documents and the interviews.

In addition to this introduction, the article includes an overview of the recent evolution of the normative framework of trade defense in Brazil that paved the way for the PBM. The third section explores the main points of change contained in Decree 8,058/2013, and some outcomes already observed. In this regard, the first two subsections of this item are related to the measures adopted to reduce the delay in anti-dumping investigations, firstly by reinforcing the state capacities of this area with the hiring of new foreign trade analysts and, secondly by expanding the dialogue and exchange of data and information with the private sector. On the other hand, subitem "Anti-dumping in Sight of the Public Interest: The Creation of GTIP" addresses 
the political treatment given to the configuration of the concept of public/ national interest that plays a key role in the context of these investigations.

The following topic ("Against the Tide: The Question of the Enforcement of Lesser-duty") examines the controversies involving another item considered contentious in anti-dumping procedures and which has been the subject of extensive discussions under the reform in question: the ideal threshold of taxation limits to be applied in proven cases of unfair competition (whether full or lesser duty). After describing and analyzing the new Decree, the text ends with a few words by way of final considerations.

\section{Continuities and Ruptures of the Regulatory Framework for the Application of Antidumping Duties in Brazil}

Contingency measures as a temporary instrument of protection can be interpreted as the ideal initiative to provide the private sector with better conditions to face international competition. This hypothesis can be tested in some of the measures of the Greater Brazil Plan (PBM), introduced in August $201 \mathrm{I}$ as a possible solution to the impasses of the Brazilian industrial policy. Authors such as Veiga et al. (2013) evaluated that in the wake of these Plan's goals, a high level of involvement emerged in the trade policy in the first biennium of the first Dilma administration (2OII-20I4).

In fact, this statement is coherent when the more gradual compass of the trade defense policy of the Lula administration is put into perspective. As previously mentioned, the major changes took place in administrations prior to Lula's, and were triggered by the decision to deepen the liberalization of the existing trade. The Cardoso administration, by internalizing all of Brazil's multilateral and regional commitments, replaced the 1987 Antidumping Agreement - based on the Tokyo Round AD Codes, and was responsible for creating a specific department to address the topic in I995: the Department of Trade Defense (DECOM), linked to the then Ministry of Industry, Trade and Tourism.

The trigger for a new wave of important changes occurred in the wake of the 2010 post-election period, when "the significant growth of imports [42\% in 20I0] and the loss of participation of manufactured products in the total exported figure [39.4\% in 2010], motivated increasing pressure from the industrial sector for greater activism in trade policy" (Cindes 20II, p.I). To operate the Portfolio of Development, Industry and Foreign Trade (MDIC), the Dilma administration indicated a name from the political-party sphere and with close proximity to the President. The chosen person, Fernando Pimentel, 
was part of the board of the Palmares Revolutionary Armed Vanguard (VARPalmares), an organization of which Dilma Rousseff was part of.

At the head of the MDIC, Fernando Pimentel (20II-20I4) found himself in the middle of a dilemma between prioritizing macroeconomic stabilization or stimulating exports as a vector of economic growth recovery in the drive to reverse the decline of the external accounts. According to Corrêa and Gomes (20I8), despite the benefits of international trade are known, many countries adopt trade policies in order to protect the domestic market from foreign competition. In his inaugural speech, the Minister affirmed that the biggest challenge for the foreign trade policy, in addition to high interest rates, would be to face the ${ }^{5}$ appreciation of the Real while other currencies would be over-depreciated (Rodrigues 20II).

In the middle management, after a sequence of directors coming from DECOM (usually former employees of the earlier Foreign Trade Portfolio of Banco do Brasil - CACEX), Felipe Hees took over the department. Economist and Diplomat for the Ministry of Foreign Affairs (MRE), having experience in trading on the topic of trade defense in Geneva (2003-2007), Hees was in the department from April 2OII until March 20I4.

The transition of DECOM to the MRE's control was not well regarded internally, since MDIC civil servants "felt dishonored" (Landim 20II). It is worth mentioning that the character of the MRE and the MDIC's employees is different. While in trade the specific character of the role is a condition, as in the case of DECOM, which applies international trade rules, at Itamaraty, diplomats have more broad skills (interview with Felipe Hees, former DECOM Director, 20II-20I4). The strangeness, or "surprise", being the term the Director used in the interview, emerged mostly from the consultancies or the media and industry, as determined, since he was isolated in Geneva. Therefore, he was unknown in the consulting and industry offices that had transit within the DECOM located in Brasilia. However, the timing and his relationship with the ACEs, working for the MDIC in Geneva, were all factors that led him to DECOM.

"I was called by Tatiana [Tatiana Lacerda Prazeres, ACE of the MDIC and then Secretary of the Foreign ${ }^{6}$ Trade of Minister Pimentel, 20II-20I3] to take over DECOM. [...] She and other analysts (Marcos César Saraiva da Fonseca, Director of DECOM, 20I4-20I6) had previously worked with me on

5 In the case of anti-dumping duties, the exchange rate, in addition to other macroeconomic variables and economic conditions, may affect the industry's demand for further investigations

6 Tatiana Prazeres was appointed by the Deputy Minister of the Ministry of Development, Industry and Foreign Trade (MDIC) of the Dilma administration, Alessandro Teixeira. 
trainings at the Permanent Mission in Geneva. I had a good relationship with the MDIC [...]" (interview with Felipe Hees). This report completely erases a discontinuity hypothesis in DECOM's internal policies due to a change of command in the Trade Policy Management.

However, MDIC and MRE established a very profitable horizontal relationship in Geneva, since the training of DECOM-linked ACEs went through the Mission program in Geneva. Thus, Hees had the technicality and, most importantly, the right contacts in the staff of the Department for which he was appointed - this was an indication from the Secretary of Trade, Tatiane Prazeres. That said, the course was not affected, that is, changes happened, but those were within the continuity which served as remediation. Consequently, Hees' time in office in the MDIC soured relations and did not violate the esprit de corps of the Ministry of Trade and also highlighted how important people are for the policy.

The Greater Brazil Plan (PBM/20II-20I4), had its creation conceived in the first semester, but only on August 2nd, 20II it became the successor plan for the Productive Development Policy (PDP/2008). The challenge of the Plan, part of Dilma administration's pledge, was to sustain inclusive growth in an adverse economic context. For that purpose, the Plan estimated five Structuring Guidelines (Des), according to Table I that follows, being the first focused on coping with the process of replacing national production in sectors subject to external competition.

\section{Table 1: Dimensions of the Greater Brazil Plan}

\begin{tabular}{|l|l|}
\hline \multicolumn{1}{|c|}{ Structuring Dimension } & \multicolumn{1}{c|}{ Systemic Dimension } \\
\hline a) Strengthening of Production Chains; & a) Foreign Trade; \\
\hline b) New Technological and Business Skills; & b) Investment;. \\
\hline c) Electricity Supply Chains; & c) Innovation; \\
\hline $\begin{array}{l}\text { d) Diversification of Exports and Internatio- } \\
\text { nalization; }\end{array}$ & d) Vocational Training and Qualification; \\
\hline e) Natural Knowledge Economy Skills; & e) Sustainable Production; \\
\hline & f) Small Business Competitiveness; \\
\hline & g) Special Actions in Regional Development \\
\hline
\end{tabular}

Source: MDIC (2012).

The Plan was composed of important measures aimed at the reduction 
of tax burdens on investment and exports. The actions sought to confront the exchange rate appreciation with an increase in the supply of credit, and prioritization for the improvement of the regulatory framework of innovation and trade defense. Furthermore, there was a clear goal of providing the Brazilian manufacturing sector with better conditions to face international competition.

In foreign trade, four routes were followed, namely: a) reduction of tax burdens; b) expansion of funding; modernization of the normative legal framework for c) trade defense; and d) protection. A total of 35 measures were projected by the Plan, which also had I5 defined targets. One of them was to expand the Brazilian overall participation in the international trade from $1.3 \%$ in 2010 to I. $6 \%$ in 2014.

In May 20II, Minister Pimentel reaffirmed a commitment of the PBM: To expedite deadlines and also to review other topics of the former AD Decree. During his management, numerous decisions covered trade policy, among which there were a set of measures that sought to increase the effectiveness of the handling of the Brazilian trade defense. With regard to deadlines, many of the measures of the Pimentel management look identical to the ones from the New Strategy of the Brazilian Trade Defense System, belonging to one of his predecessors - Minister Luiz Fernando Furlan (2003-2007).

Although the Dilma administration has implemented the first - and single - wave of modernization of the regulatory framework of trade defense in Brazil, this opportunity was born before her presidential term. During a Seminar on Trade Defense, held in September 2003, the then Minister of Development, Industry and Foreign Trade, Luiz Fernando Furlan, Lula's Prime Minister, announced his plans for Brazil's trade defense. The "New Strategy for the Brazilian Trade Defense System (NESBDC)", as it was called, was divided into eight items to strengthen DECOM. This evidence shows an intention of reform announced, formerly, in the Lula administration, and only carried out with the PBM. Pimentel also announced specific measures for trade defense, such as:

a. the possibility of applying anti-dumping duties equivalent to the dumping margin - the end of lesser duty;

b. intensification of the fight against false declaration of origin;

c. boosting the fight against underpriced prices and illegal imports;

d. predicted the creation of the Foreign Trade Intelligence Group (GI-CEX);

e. sought to reinforce the requirement of compulsory certification 
through affiliation with Inmetro, SECEX and the Internal Revenue Service.

Regarding the deadlines for the investigation of dumping, safeguards and subsidies, the PBM first sought to reduce the investigation deadline from I5 to Io months - an intent set forth in the NESBDC. The PBM would still prioritize the determination of provisional duty application within $\mathrm{I} 2 \mathrm{O}$ days, given that the ADA norms have maximum deadlines of only I8 months this item also maintained a relationship with the NESBDC. The PBM was emphatic in its desire to increase the number of trade defense investigators from 30 to I2O, as well as to make the application of provisional duties and the preliminary determination compulsory.

With systemic and horizontal impact on production chains, trade defense measures were then contemplated within the foreign trade level. According to the Portfolio's Minister, the PBM would focus on innovation and the productive densification of the Brazilian industrial park, in addition to defining, for the trade defense, a place of importance in the list of priorities of the Dilma administration (Pimentel 20I3).

\section{The New Brazilian Trade Defense: PBM Concrete Results}

As part of a campaign promise from the Dilma administration, great emphasis was placed on the industry's desires. The reduction of the delay in investigations conducted by DECOM would depend, among other actions, on the expansion of the staff number of Foreign Trade Analysts (ACEs) in the Ministry of Development, Industry and Foreign Trade (MDIC), followed by changes in the modus operandi of the initial part of the investigation. Nevertheless, other measures discussed in public consultation would also be successfully implemented during Dilma Rousseff's first administration. Progressively, the new regulatory framework was being released through a chain of Resolutions and Ordinances that, together, allowed the crystallization of a new AD Decree. The document, from July 29th, 2013, introduced by Decree No. 8,058, in force since January Ist, 20I4, replaced Decree No. I,602/I995 concerning the regulation of investigation procedures and the application of anti-dumping measures.

According to Prazeres (interview with the Secretary of Foreign Trade of that period), "Trade defense gained an importance that it did not have before in the Dilma administration, because some circumstances favored it. This was Dilma's insight, and also an insight of the Minister of Industry, it 
was an industry distress. It was a time when Brazilian imports grew at an accelerated rate. We came from a recovery of the international financial crisis, the Real was appreciated, as a result, imports in Brazil began to increase, this way, the industry mobilized efforts to find a government sensible enough to care for industrialization and national development". For the interviewee, it was the economic and political circumstances that allowed a joining of adequate efforts to enable not only a new Decree, but the largest public tender. "We saw an opportunity to make a series of reforms that we understood to be important. We took great advantage of that political momentum; this is something that happened at that specific moment".

Although the scenario was favorable, to have a President sign a new decree would not be an easy task, especially when the idea came from the middle management. "We value and draw attention to the importance of the trade defense to make the industry stronger. If a goal of the Plan was reached, we could mobilize the efforts and resources of the administration. When the Plan was conceived, and if they recognized the importance of the trade defense, we could raise the efforts and resources to strengthen the field".

First, it was necessary to convince the Chief of Staff (Casa Civil) that the matter was important enough to become part of the government directives. However, the topic was very technical, "someone needs to explain these premises to the President, she needs to take notice, someone needs to enlighten her, convince the Chief of Staff that this was the Decree that we needed. No one thought that the Decree was a priority until we entered the final phase of its drafting".

\section{The ACEs to Attack Investigation Delays}

The items listed in the PBM or by the Minister, in their own way and in their time, were pursued and concluded under the MDIC. As the number of investigations grew, so did the desire to attack their delays, and the idea of increasing the number of analysts found ground to thrive. The number of investigators at DECOM fluctuated around two dozen at the time (interview with Ana Carolina Peres, Foreign Trade Analyst and Coordinator of DECOM). The need for reinforcement in the Department's team of investigators (which wasn't a new state of affairs) worsened with the increase in the number of investigations between 20II and 20I3 (only between 20II and 2012, 63 new investigations were opened).

Being the Department's practice to delegate an investigation to a pair of investigators, each trade analyst should have at least five ongoing 
investigations. A public tender to hire new ACEs was then considered a priority.

Minister [Pimentel] affirmed, when we were developing the Greater Brazil Plan: "I need to deliver something to the industry [referring to the issue of the investigations delay, given that this was an old industry's demand]". I replied, "So, first of all, we need to have more investigators, only then we change the regulatory framework which plays against the goal of faster speed [referring to the old philosophy of Decree I,602/I995]". The increase in the number of investigators was decided between April and May in order to be included in the Plan that was to be released. The regulation reform, on the other hand, was finalized only in July 20I3 (interview with Felipe Hees).

The issue was so latent that even after the appointment of the 157 new Foreign Trade Analysts, from the first call-out, the MDIC managed to increase the number of analysts with the call-out of other candidates that passed the public tender. "Just over a year after my appointment, still dozens more were called [referring to Ordinance No. 202/20I4]" (interview with Gabriela Verenhitach, Foreign Trade Analyst of the MDIC, appointed by Ordinance No. 63/2013). The hiring of public servants at the Department of Foreign Trade and the training (through a specific master's degree created to train the new ACEs) represented an extensive restructuring of the agency. However, not all new servants were allocated to DECOM. Although it was not possible to accurately determine the number of analysts allocated to DECOM, it is estimated that there were at least 35 ACEs (interview with Márcio, Foreign Trade Analyst appointed by Ordinance No. 63/2013).

At DECOM, the number of technicians increased, but other MDIC departments took the opportunity to absorb some of the analysts. "When the public tender was organized, the idea was that every successful candidate was going to be allocated at DECOM, however, at the swearing-in ceremony we were told that we would be working for different departments of the MDIC and not only for DECOM" (interview with Gabriela Verenhitach).

This is a convergent point in the interviews, both on the valorization of the new ACEs and the criterion for the allocation of new approved candidates.

"The Minister attended and symbolically placed the badge on Abrão [Abrão M. Árabe Neto], who got first place in the exam, but the ceremony was for everyone. The idea was to inflate the DECOM's staff number, but there was a lot of demand from other sectors. Each sector made a claim, informing how many analysts they needed, as a result, the Department allocated them. First, at the end of the training course in December 20I2, the Deputy Minister 
[Alessandro Teixeira] affirmed that they would gather everybody in the same room, by order of classification, and each would have the right to choose where they wanted to be allocated to. But in practice, on the inauguration day [in February], they even told us in the microphone: 'Oh... Tomorrow you call the HR to find out what sector you will be allocated to.' Basically, the top Ioo candidates were allocated to SECEX, of those, some people complained, and they managed to change the allocation. Some people requested to be allocated for a specific sector and, when possible, their request was met. And others were placed in other sectors. This information is not documented, but that's how it happened" (interview with Gabriela Verenhitach).

The process evolution to allocate the new ACEs can be verified in the following table.

\section{Table 2: Creation and Appointment to the Role of Foreign Trade Analysts}

\begin{tabular}{|c|c|c|}
\hline Government & Instrument & Content \\
\hline \multirow{5}{*}{$\begin{array}{l}\text { Dilma Rousseff } \\
\text { Fernando Pimentel } \\
\text { (MDIC) }\end{array}$} & $\begin{array}{l}\text { Law I2,545, of De- } \\
\text { cember I4, 20II } \\
\text { (Federal Official } \\
\text { Gazette [DOU] } \\
\text { I2.I5.20II) }\end{array}$ & $\begin{array}{l}\text { Art. I4. In the Federal Executive Branch, I20 } \\
\text { (one hundred and twenty) positions of effec- } \\
\text { tive provision of Foreign Trade Analyst (ACE) } \\
\text { were created, of the profession of same name }\end{array}$ \\
\hline & $\begin{array}{l}\text { Ordinance MPOG } \\
\text { No. } 608 \text {, of Decem- } \\
\text { ber } 28 \text { th, } 201 \mathrm{II} \\
\text { (DOU I2/29/20II) }\end{array}$ & $\begin{array}{l}\text { Authorizes the performance of a public ten- } \\
\text { der in order to hire I57 ACEs }\end{array}$ \\
\hline & $\begin{array}{l}\text { Ordinance No. } 63 \text { of } \\
\text { February } 26 \text { th, 20I3 } \\
\text { (DOU } 02.27 .2013)\end{array}$ & Appointment of new Foreign Trade Analysts \\
\hline & $\begin{array}{l}\text { Ordinance MPOG } \\
\text { No. I44, of May } \\
\text { 6th, 2014 (DOU } \\
\text { 05.07.2014) }\end{array}$ & $\begin{array}{l}\text { Authorizes the appointment of other } 67 \\
\text { ACES from the list of the public tender held } \\
\text { by the previous notice }\end{array}$ \\
\hline & $\begin{array}{l}\text { Ordinance No. } 202 \text {, } \\
\text { of July } 29 \text { th, } 2014 \\
\text { (DOU } 07.30 .2014 \text { ) }\end{array}$ & Appointment of new ACEs \\
\hline
\end{tabular}

\section{Source: Elaborated by the author.}




\section{Reducing Delay: Editing New Rules}

In addition to the largest hiring of Analysts since the position was created, the second stage was the edition of CAMEX Resolution No. 44, which established the Interministerial Technical Group for the Consolidation of Internal Foreign Trade Legislation (GTIC). The latter was assigned to prepare a proposal for the modernization and consolidation of the domestic legislation, in order for it to be standardized, rationalized and simplified. By Art. 4 of the said Resolution, the Group should survey the legislation relevant to the trade in force to draft the modernization project. The attempt to speed up investigations and detail procedures then depended on the creation of a working group to draft a more efficient legislation. According to the Secretary of Foreign Trade at the time, "the replacement of the old normative framework, which dated from 1995 and was no longer up to the contemporary challenges of the Brazilian foreign trade, was fundamental to the fulfillment of the two central goals of the Plan on that matter" (Prazeres 2011).

During an interview, Tatiana Prazeres recalled that in the DECOM's modus operandi, a set of practices and procedures were adopted in the investigations, which were based on the interpretations of the Geneva Center for International Dispute Settlement, but that were not provided for by the decree in force - referring to the 1995 Normative Framework. By the - developmental - general line of the Dilma administration and the Treasury, in the role of the Minister Mântega, "We were always trying not to make mistakes. We debuted half of the requests for opening of an investigation, and after opening, half of the application requests were not deferred. There was much political pressure in regard to the understanding that that government was more opened and sensitive to the industry demands. [including] ACEs in charge of the investigations had the habit of meeting to win coherence and cohesion between investigations". The new Decree would still "embrace all DECOM's experience in investigations, much of the practice accumulated in actual issues".

According to Prazeres, the Decree "deliberately decreases the gray area, so it has reduced the administration's room for maneuver by establishing strict deadlines and criteria". These actions were always intended to preserve the status of the Brazilian Trade Defense in the WTO Dispute Settlement System, after all, the country never had a decision of DECOM condemned. "The drafting of a new Decree must be a mirror of the ADA, [including] maintaining the ambiguity of its wording. This ambiguity allowed for this agreement. We cannot try to improve the Agreement. The provisions of the Agreement do not change in the Decree".

According to the Secretary of Trade at the time, this matter involved several spheres of the Executive Branch. On the one hand, there was some 
difficulty in "passing the matter due to the distancing of the Legal Department of the Chief of Staff". The concern of those in charge was the ambiguity of certain items in the text, which followed the wording of ADA. On the other hand, during the investigations, communications with the Internal Revenue Service had to be adapted "in order to regularize data sharing so that the deadlines established in the Decree could be met". On their part, the "Treasury Department did not show great resistance and was more concerned with inflation issues", a matter that was eventually discussed in the Technical Group of Public Interest - established in the same management.

Its result was Decree No. 8,058/2013, which increased from 73 to 201 the number of articles in the Brazilian anti-dumping legislation. The issue of the new regulatory framework was in line with changes made by Ordinance No. 46/2011, since it had already concentrated the burden of data submission in companies. With extra information during the pre-claim stage, it would be possible to influence the speed of investigations. According to Panzini \& Souza (2013), with the late insertion of Brazil in the international trade system, the requirements for opening an investigation were more simplified and the handling of the entire investigation was guided by a collaborative line between the investigating authority and the Brazilian private sector. Therefore, for the authors, a broader system made it possible to create the culture of trade defense in the Brazilian industry, but, in return, made the process slower?.

Through SECEX Ordinance No. 46/2011, the new guidelines for the dynamics designed by DECOM have changed the requirements for conducting anti-dumping investigations. The Ordinance had all the relevant information to integrate the petition form necessary to open an investigation. The volume of requested information increased as he anticipated the "request for various information that would be provided by the petitioner after the beginning of the investigation" (Pimentel 2013, p. 65). Therefore, the Ordinance began to demand more intense work between industry and offices/consulting services throughout the pre-investigation period. During an interview with the former Director of DECOM at the time, and with Coordinator Ana Carolina Meneghetti Peres, what prevailed was an understanding that this strategy aimed to reduce the time wasted during the information complementation phase - there was constant contact of the investigating authority and the industry in order to fill out the information and data.

This measure can be interpreted as an attempt to speed up the deadlines for conducting the investigation or restrict the access of "adventurers" to the protocol of investigation requests (the latter being disregarded by Hees in an

7 Goldbaum \& Pedrozo Jr. (2019) explained that the average time of an investigation in Brazil was higher than the international average. 
interview). According to the former Director, the measure resulted in a faster investigation in addition to being in line with the new provisions set forth in Decree 8,058/2013 - which sought to apply the provisional duty more quickly (120 days), since DECOM, in the preliminary issuance of an opinion began to use the data provided by the petitioner.

In addition, this was an industry demand presented during seminars between class entities (such as CNI and FIESP), and in public consultation, with mentions for faster deadlines since previous governments. With the increase in the volume of information requested for opening an investigation, it was then possible to establish a maximum period (60 days) for the analysis of the petition as provided for in Decree 8,058. Furthermore, the text of Article 72 of this Decree was made possible, and it established a 10-month deadline for the closure of an investigation - extendable in special cases.

\section{Anti-dumping in Sight of the Public Interest: The Creation of GTIP}

In line with the Multilateral Trade System, the Dilma administration sought to reflect on the need to impose anti-dumping measures, as well as on the effects of these barriers for the final consumer - a concern of the Treasury. The Resolutions issued by CAMEX prior to the PBM already referred to the public interest using the term "national interest". Since "public interest" is a concept with high plasticity and multiple meanings, it is worth mentioning that national interest refers to aspects related to national security, while public interest is fundamentally associated with the economic consequences, for the country as a whole, of the application of an AD measure (Hees 2013).

Although the analysis of national interest was historically considered by the Executive, even if sometimes conceptually mistaken, until the PBM came into effect, there was not even an institutionalized procedure for the evaluation of AD measures and their repercussion on the industry and end consumers. In the compilation of Resolutions issued between I988 and 2015, I3 cases of national interest were considered and mentioned. These ranged from products such as peach preserves to steel materials and chemicals. Shoes can also be included in this account, since CAMEX, through Resolution No. 48, of September 2009, when applying the provisional duty for six months, took into account that the national interest was considered in the AD calculation. The then Minister Miguel Jorge welcomed the "increase of the Import Tax for products covered by this measure during the investigation period, in order to avoid excessive burden on the population with lower purchasing power" (Brasil 2009). 
In the meantime, after almost a dozen cases of suspension or amendments to measures that have involved the national interest and the application of $\mathrm{AD}$ duties, the idea of creating a Group to assess the public interest was strengthened. The search for the assessment of the existence of public interest would aim to include the analysis of the impacts of the protection measure on the final prices of the products mentioned in the investigation, in addition to considering the cost on the companies upstream of the production chain. For Hees (20I3), the Technical Group of the Public Interest (GTIP) would be a technical body within CAMEX, whose initial function would be to review petitions relating to the public interest in the context of dumping investigations and existing AD measures.

We emphasize that in the WTO trade defense agreements there is no express provision for such an assessment. Only a few WTO members, such as Canada and the European Union, have adopted rules in their legislation applicable to the public interest assessment (in the EU we have a Community Interest) for the purpose of deciding to implement trade defense measures.

In the case of Brazil, the effort to guide domestic interests in order to incorporate a formal scope of consideration of the impact of these measures came from within DECOM. In an interview, we pointed out that the idea of creating the Group came from the then Director Felipe Hees, and started to gain structure through the Resolution No. I3/20I2, responsible for establishing the group for the evaluation of the public interest.

In the sphere of class entities, CNI (2OI2) endorsed the GTIP Public Policy and suggested only that this Resolution should have a definition of national interest, such as "the sum of all private interests", therefore considering end consumers or industry. During an interview, the Coordinator of the entity's report, Eduardo Freitas Alvim, agreed on the broad discussion of the Group's implementation. Alvim added that the Group's implementation only followed the trend, since Canada and the European Union already have one (but the United States does not).

According to the reports and resolutions submitted post-GTIP, the first requests submitted by the parties opposed to the application of measures were not assented. Between its creation and 20I4, it was found that, in the case of decisions associated with measures applied in force, in all cases claimed, CAMEX maintained the measures applied, except in one request — which became the first after the creation of the GTIP.

On May I6, 20I3, of the investigations of Public Interest, Resolution CAMEX no. 35/2013 was published, which suspended, for reasons of public interest, until July 3ISt, 2OI4, the collection of anti-dumping duties and definitive and provisional countervailing measures on imports relating to the 
Events of the 20I3 FIFA Confederations Cup and the 20I4 FIFA World Cup.

When the research examined the official documents that circulated between delegations in Doha, this point was discussed through submission of a proposal demanding that the public interest be taken into account effectively when deciding to apply AD measures. Item I2, set forth in document TN/RL/ $\mathrm{W} / 6^{8}$ of 2002 , involves the discussion of imposing such an obligation on the investigating authority. Thus, in the set of documents, this matter was raised by different delegations, including Brazil.

After the publication of Resolution No. 13/2012, Art. 3 of Decree $8,058 / 2013$ deliberates on the issue of the GTIP, sinceitrules that, in exceptional circumstances, the Council of Ministers (CAMEX) may, in the public interest: Suspend, for up to one year, extendable only once for the same period, the enforceability of definitive anti-dumping duty, or price commitment in force; not apply provisional anti-dumping duties; or approve price commitment or apply definitive anti-dumping duty in a different amount than recommended.

\section{Against the Tide: The Question of the Enforcement of Lesser-duty}

Another progress, and perhaps the most controversial one from Decree 8,058, resulted from the Doha discussions at a matter where Brazil followed the Friends of Antidumping ${ }^{9}$ (FANs). In document TN/RL/W/ $/ 6^{\mathrm{IO}}$, which was going around in the group, from April 2002, item tenth discusses Art. 9.1 and was in favor of making the principle of lesser duty rule. According to ADA, "[...] it is desirable that the imposition be permissive in the territory of all Members, and that all the duty be less than the margin if such duty would be adequate to remove the injury to the domestic industry" (Art. 9.1). Therefore, the ADA, at the same time that it provides, also declares that it is desirable to follow this principle since it seeks only to neutralize the practice. In 2005, once more the Brazilian position would be strengthened when Minister Luiz Fernando Furlan, Prime Minister of the Lula administration, ratified this will.

8 Anti-dumping: Illustrative Major Issues. Document submitted by: Brazil; Chile; Colombia; Costa Rica; Hong Kong, China; Israel; Japan; South Korea; Mexico; Norway; Singapore; Switzerland; Thailand and Turkey.

9 Group of developed and developing countries that jointly seek to submit proposals during Ministerial Meetings in Doha to increase transparency and restrict the indiscriminate use of AD measures.

IO According to the document, the "current AD Agreement encourages, but does not require the importing country to apply the 'lesser duty' a duty no higher than that necessary to offset any injury being suffered by the domestic industry. Given that $A D$ duties are specifically designed to counteract injury being suffered by the domestic industry, is it appropriate to apply $A D$ duties that are higher than necessary to counteract that injury?" (WTO, 2002). 
Using the lesser duty rule as a thermometer, we understand that the convergent position with the FANs on the rules table is more inclined to legitimize the Multilateral Trading System than the other way around. The application of the lesser duty continued to guide other DECOM reports (the last to mention it was the DECOM Report, no. 13, of 2009). Years earlier, there was an emphasis expressed by the director of DECOM at the time, Fernando de Magalhães Furlan.

Brazil uses, unlike many other countries, the lesser duty rule for the application of this trade defense measure. Brazil applies the AD duty only to the necessary extent to eliminate the injury to the domestic industry. To this end, the Brazilian authority uses the underpricing margin, that is, the underpricing is assessed by comparing the import price, under the landed cost CIF condition, and the sale price of the national product, in the ex-works condition. Thus, the product imported at dumping prices will only pay the anti-dumping duty to the exact extent in order to equalize it to the value of the domestic product (Brasil 2007).

As Lemme and Naidin (2011) recalled, Decree 1,602/1995 seemed to have made the recommendation to apply the lesser duty principle whenever satisfactory to eliminate the damage resulting from imports at dumping prices. However, the authors, when analyzing almost a hundred resolutions published by CAMEX between 2001 and 2011, showed that full margin decisions predominated (73\%) over the number of duties that followed the principle.

Prior to the issue of Decree 8,058/2013, public demonstrations were observed through online consultation that received a series of proposals that came from law firms, consultancies, class entities, exporters and importers. On the one hand, MOVE (2011), Association of Producers and Importers of Sporting Goods - the target of protective measures against Chinese footwear, for example, advocated the change for issues such as the smallest margin (lesser duty), proposing that the old Art. 45 were to defer the duty corresponding to the smallest margin found. Whereas FIESP (2011) expressed their opposition, and requested that a full margin be applied in the new Decree replacing the practice of the smallest margin.

The controversy began because of ${ }^{\mathrm{II}}$ a statement by Minister Pimentel, who among the series of possible adjustments, mentioned that Brazil would apply the full margins of anti-dumping tariffs, changing one of the program's goals in Doha.

II Landim, Raquel. 20II. "Tightening the Anti-dumping Screw”. Estadão, São Paulo, from May 2, 20 II. Moreover, in an interview with Felipe Hees, he revealed more details of the episode: "Yes, I remember, it was even discussed at one of CAMEX meetings at the time. Perhaps you find in the 2oII Resolutions, otherwise this should appear in some of the Minutes of the Chamber" (Interview with Felipe Hees, former Director of DECOM). 
The demand was submitted to CAMEX, which began to consider its incorporation into the new Decree, since it emerged as a demand coming from the industry. However, this attitude before the WTO and the FANs has become contradictory.

Ultimately, the $\$ 1$ of Art. 78 of the new Decree established that the duty to be applied would be lower than the dumping margin whenever an amount lower than that one was enough to eliminate the injury to the domestic industry caused by the imports under investigation. Thus, the text of the new Decree, by making the lesser duty the rule, contradicted part of the industry, but it was enough to keep compliance with the multilateral trading system principles.

Another progress of Article 78 was the text of $\$ 3$, which laid down the conditions for the situation in which the application of the full margin is indicated. As announced by Pimentel, the government sought to discourage importers who were tempted to anticipate the imposition of the anti-dumping measure. This behavior, according to the new Decree, can be interpreted as illicit. In turn, such a finding leads the investigating authority not to extend the lesser duty to companies and importers with dubious conduct - or for lack of cooperation during investigations.

\section{Checks and Balances of the Trade Defense During the Rousseff Era}

During the Dilma Rousseff administration, the modernization of legislation aimed at international trade was put in place, which was intended by DECOM and awaited by the civil society sectors. In this sense, the increase in the number of cases and investigations encouraged the discussion towards an immediate modernization of anti-dumping legislation in order to provide transparency and ensure the honesty of investigations over unfair practices employed in Brazil's trade with foreign institutions.

Taking into account the highlighted set of aspects, the changes introduced by the new Decree reduced the margin of discretion of the Brazilian investigating authority. Its new wording caused per se, the shortening of the reach of the "sword" of trade defense in Brazil, while it also provided a greater compliance with the principles of the multilateral trading system.

Decree 8,058/2013 was not the only element in the modernization of the regulatory framework, since it was preceded and succeeded by a series of Ordinances. However, it is the greatest element in this inflection of trade defense in Brazil. Since, in addition to the aforementioned changes, the new regulations for the application of anti-dumping measures would also incorporate greater transparency through more detailed procedures for the investigation and analysis stage, as well as in the calculation of the dumping 
margin and injury determination. In relation to the calculation of the dumping margin, some details can be seen as more restrictive for exporters. On the other hand, there are also stricter requirements for determining causality between alleged dumping practice and damage to domestic producers (Hees 2013).

According to FIESP (2OI3), as a concrete outcome, the details of the investigation included the introduction of new concepts, such as "product subject to investigation", which did not exist in the WTO Agreement, but which already reflected the international practice. There was also the inclusion of clearer procedures for the treatment of economies classified as non-market, which relate criteria for their definition and for the selection of substitute country and price development. Other procedures were also incorporated, that is, those that were already being adopted by DECOM related to anticircumvention investigations ${ }^{\mathrm{I2}}$, reassessment of scope of products subject to duties collection and the end of the final hearing - waived due to the creation of the Digital DECOM System.

When Hees (2009) analyzed the Brazilian investigation process, he stressed that the determination of injury is the investigation's key element, and also the most controversial. "Either by the subjective dimension of the analysis or because of the scarcity of clear guidelines in the Anti-Dumping Agreement, the fact is that the work of investigating authorities in this field is often criticized for the discretion and abuse with which they are conducted" (Hees 2009, pp. 58-59). It is not surprising that the presence of such a margin for discretion has produced numerous disputes in the DSU, in addition to being featured in the center of a large number of documents that referred to the determination of injury (Article 3 of the ADA) during discussions in Doha $^{\text {I3 }}$.

As can be seen, the commercial policy, although being surrounded in criteria and indicators that re-establish a certain degree of technicality, is inexorably contingent and subject to the vicissitudes and preferences of the actors that boost it. The conduct of the Brazilian trade defense policy, when studied from the use of the AD regime, suggests latent differences over time and between governments without tarnishing its credibility.

I2 Reference to SECEX Ordinances No. I4/20II and No. 44/20I3.

I3 However, after considerations in numerous formal and informal delegation meetings, Doha had a total of I8 proposals for changes until April 2002. From July 2004 to 2009 , I4 proposals with specific suggestions circulated in relation to Article 3 (Hees 2009). 


\section{Final Remarks}

On the long road to consolidate the opening of trade in Brazil, trade defense had its role almost always relegated to the background. Still, there was a time when anti-dumping measures became a fundamental part of the Brazilian trade policy. With the growth in the number of measures imposed, the exposure of the Brazilian foreign trade policy was inevitable. Therefore, the article sought to describe how the ADA normative framework has evolved in the country, since the I990s, and how the referrals of this process reflect a tendency to endorse the rules of the multilateral trade regime.

In traditional countries, the first laws emerged in the beginning of the 2oth century, while in Brazil the first AD Legislation was, above all, a reflection of the launch of the Uruguay Round. That said, the creation of a specific department for the matter came in turn in the wake of the conclusion of the Uruguay Round, to the extent that it was demanded by the person responsible at the time (Luiz Felipe Lampreia) and provided for in the government plan of the FHC government.

At the same time that Brazil ascended to the group of the largest users, there was also growing criticism of the legislation in force, which was considered outdated since it was created in the wake of the Uruguay Round negotiations. The modernization of the normative framework then became the center of attention of the Greater Brazil Plan. To meet an old industry demand in order to deliver protection more quickly, the Department needed to "call for reinforcement" and I20 new Foreign Trade Analysts were announced by the PBM, and more than 200 ACEs were called in the same public tender.

The reduction of deadlines and the enforcement of standards that are already applied, but not determined by the former Decree, catalyzed the reform of the regulatory framework for the enforcement of the AD duties. The change of philosophy, as Hees called it, was an idea that was born in the first Lula administration and only consolidated in the Dilma Rousseff administration. Therefore, when observing the Dilma administration, all evidence points out for a continuity of the foreign trade policy, which was strengthened through an adjustment in the structure and philosophy of the Department.

Moreover, during the Minister Pimentel administration, more elements with matters that deserved further attention existed. First of all, we highlight a program change (lesser duty) that appeared with the new Minister. A second element of discontinuity was related to the direction of DECOM, with the arrival of Felipe Hees in the management of Minister Pimentel. As mentioned, the character of the MRE and the MDIC professionals are 
different. However, the MDIC and the MRE established a smooth horizontal relationship in Geneva, as the training of DECOM-linked ACEs went through the Mission program in Geneva. Therefore, Hees had the technicality and, above all, the contacts with the staff of the department for which he was appointed - indication of the Secretary of Commerce, Tatiana Prazeres. That said, the course was not affected, that is, changes happened, but those were within the continuity which served as remediation. Thus, its transit through the MDIC soured relations and did not violate any esprit de corps of the Ministry of Trade and also stressed the importance that the individual, in the role of a technocrat, has for politics.

All the points raised contributed to reveal elements that reinforce the idea that the trade defense in Brazil is more about reducing discretion than the other way around. However, the new Decree aimed to reduce the deadlines of investigations, which seems a more protectionist stance. Meanwhile, considering that the time of investigation in Brazil is longer, and that the new deadline established respects the ADA, this hypothesis could be relaxed. In any case, this research is not intended to be an end point in the debate, and many other points or cases could be considered to reinforce the discussion.

The analytical effort imposed in the course of the research has managed to close many gaps in previous research plans. However, other axes of investigation around this issue remained open, resulting in multiple research agendas that emerge from its conclusion. Since we did not aim to focus the research on the creation of DECOM, or even to analyze the politicalbureaucratic game of how its creation was thought and the role of the main policy makers of the FHC era, this point remains open. There is a lot of literature on CAMEX, but very little on the institutional evolution of DECOM.

Furthermore, while observing a more recent period, it was also not possible to collect information about the phase prior to the creation of the department, or even to raise the reasons that led to the creation of the role of Foreign Trade Analyst with the MDIC and the Ministry of Planning, Budget and Management (MPOG) at the time. Still regarding this matter, there are no studies and research that sought to raise the history and the political game that culminated in the creation of ACE's own career.

Finally, the research did not find answers about the underachievement of the reform of the 1995 Decree, although it was released under the management of Minister Furlan, in the first Lula administration. Once a specific plan for trade defense was announced, it did not thrive and remained only in the paper. Nevertheless, some of the main guidelines of the NESBDC for the Brazilian System of Trade Defense of the Lula administration were successfully resumed and concluded in the Dilma administration. 


\section{REFERENCES}

Brasil. Câmara de Comércio Exterior - CAMEX. 2009. "Resolução CAMEX nffl. 48/2009". Aplica antidumping provisório nas importações de calçados chineses. Diário Oficial da República Federativa do Brasil, September 09, 2009. Access on Dec. 02, 2017. http://www.camex. gov.br/resolucoes-camex-e-outros-normativos/58-resolucoes-dacamex/844-resolucao-n-48-de-o8-de-setembro-de-2009

Bown, Chad P. 2009. "Protectionism is on the rise: antidumping investigations". In: Baldwin, Richard and Evenett, Simon (Org.). The Collapse of global trade, murky protectionism, and the crisis: Recommendations for the G20, 55-58. London: Centre for Economic Policy Research, 2009.

Bown, Chad P. 2012. Emerging Economies and the Emergence of South-South Protectionism. Whashington DC.: World Bank Policy Research. Working Paper, n. 6162, 44 .

Carvalho, Luiz M; SORG, Letícia. 20II. "O ministro e seu quase sequestro". Revista Época, mar. I8, 20II.

CINDES - Centro de Estudos de Integração e Desenvolvimento. 20II. PC em Foco: Observatório de Política Comercial. Cindes, 04 (ii): maio.

CNI - Confederação Nacional da Indústria. 20I2. Observatório de Defesa Comercial, I (I): agosto.

Corrêa, Carolina R.; Gomes, Marília Fernandes M. 20I8. "Tariff and Technical International Trade Measures: a look at advanced and emerging countries". Austral: Brazilian Journal of Strategy \& International Relations, 7 (I3): 288-316.

FIESP - Federação das Indústrias do Estado de São Paulo. 20I3. Panorama Defesa Comercial, n. I2: outubro.

Feinberg, Robert M. 20I0. "Antidumping and global financial crisis: the impact on Latin America and the Caribbean”. Studies and Perspectives series, n. 9 .

Global Trade Alert - GTA. 2009. Global Trade Alert ist Report. Centre for Economic Policy Research. Independent Monitoring of Policies that Affect World Trade: july.

Goldbaum, Sergio; Pedrozo Jr, Euclides. 20I9. "Impacto do Decreto n. 8.058/2013 sobre investigações antidumping no Brasil”. Revista Direito GV, I5 (I): janeiro/abril.

Hees, Felipe. 2013. "Interesse público e a aplicação de medidas antidumping 
no Brasil". Revista Brasileira de Comércio Exterior, n. II4 (janeiro/ março): O4-II.

Hees, Felipe. 2009. "A análise de dano em investigações antidumping: a quadratura círculo?”. Revista Brasileira de Comércio Exterior, n. Ioo (julho/setembro): 40-59.

Landim, Raquel. 20II. Troca de comando na defesa comercial, Estadão, February 25, 20II. Access on May 23, 2015. https://economia.estadao. com.br/blogs/sala-ao-lado/troca-de-comando-na-defesa-comercial/.

Lemme, Marta Calmon; Naidin, Leane Cornet. 20II. "O fim do lesser duty e suas distorções na política antidumping no Brasil”. Revista Brasileira de Comércio Exterior, n. Io8 (julho/setembro): 30-37.

LIindblom, Charles E. I981. O processo de decisão política. Brasília: Editora UnB.

Ministério do Desenvolvimento, Indústria e Comércio Exterior - MDI). Brasil Maior: Inovar para competir. Competir para crescer. s/d. 20I2. Access on Jan. 23, 20I8. http://www.brasilmaior.mdic.gov.br/wp-content/ uploads/cartilha_brasilmaior.pdf.

MOVE - Movimento para a Livre Escolha. 20II. "Manifestação". Consulta pública via Decreto I.602/1995. São Paulo.

Pierson, Paul. 2004. Politics in time: history, institutions, and social analysis. Nova Jersey: Princeton University Press.

Pimentel, Fernando Damata. 20I3. "As Investigações antidumipng e o sistema brasileiro de defesa comercial". Revista Brasileira de Comércio Exterior, n. II6 (julho/setembro): 64-7I.

Prazeres, Tatiana L. 20ıı. "A modernização da defesa comercial brasileira". Valor Econômico [Opinião], July 02, 20II. Access on Jan. 242016. http://www.valor.com.br/opiniao/3219982/modernizacao-da-defesacomercial-brasileira.

Putnam, Robert. 1988. "Diplomacy and domestic politics. The logic of twolevel games”. International Organization, 42 (3): 427-460.

Rodrigues, Azelma. 20II. "Pimentel assume MDIC criticando carga tributária e juros”, Extra, January 03, 20II. Access on Feb. 20 2015. https:// extra.globo.com/noticias/brasil/pimentel-assume-mdic-criticandocarga-tributaria-juros-8Io844.html?versao=amp.

Veiga, Pedro da Motta; Rios, Sandra P.; Naidin, Leane C. 2013. "Políticas comercial e industrial: o hiperativismo do primeiro biênio Dilma". Breves CINDES, n. 35 . 


\section{ABSTRACT}

This study considers the development and reform of the anti-dumping regime in Brazil as a ratification example of the multilateral trading system proposed by the World Trade Organization (WTO). Brazil's history of leadership in the WTO Rounds, as well as its emergence among users of temporary barriers illustrates the fact that developing countries participate, with some success, in the endorsement and strengthening of the multilateral system itself. Using the WTO Anti-Dumping Agreement (ADA) as a model for its own regulatory framework, this practice ensures that domestic legislation will have greater compliance to international obligations and avoid constraints via the Dispute Settlement Body. Finally, the case of Decree $8,058 / 2013$ highlighted the importance that specialized agents in the middle management of the Ministry of Development, Industry and Foreign Trade (MDIC) have in the management and improvement of the Brazilian public policy.

\section{KEYWORDS}

Greater Brazil Plan; Trade Policy; Trade Defense.

Received on March 3rd, 2021

Approved on March 25, 2021

Translated by Thaise Poerschke Freitas 